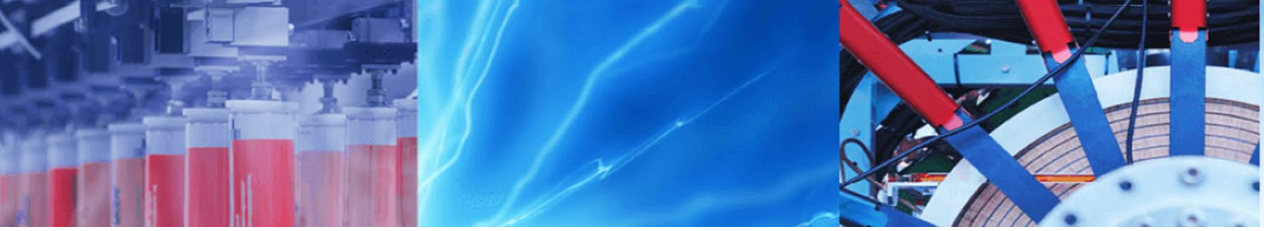

Research Article

\title{
A remote sensing and GIS-based analysis of urban sprawl in Soran District, Iraqi Kurdistan
}

\author{
Rahel Hamad ${ }^{1,2}$ iD
}

Received: 11 July 2019 / Accepted: 26 November 2019 / Published online: 4 December 2019

(c) Springer Nature Switzerland AG 2019

\begin{abstract}
Determination of spatial and temporal patterns of urban growth has become one of the most significant challenges in monitoring and assessing current and future trends of the urban growth issue. Soran district has witnessed very rapid growth in the last two decades, mostly because of its economic, commercial and social attractions. The aim of this work is to study the growth and sprawl dynamics through the land use and land cover (LULC) maps for the area at three different periods (1998, 2008, and 2018) particularly in the urban areas employing GIS and RS techniques. Three Landsat images, Enhanced Thematic Mapper plus in the 1998, Thematic Mapper in the 2008 and Landsat Operational Land (LOL) in the 2018 were used to assess the changes of urban encroachment. A supervised classification technique by maximum likelihood classifier has been employed to create a classified image and has been assessed based on Kappa index. The results obtained showed that the urbanized area increased from 4.51 to $14.93 \mathrm{~km}^{2}$ from 1998 to 2018 . This study demonstrated that the substantial changes in LULC in Soran district since the end of 1990 s are directly related to and influenced by the main and secondary roads development on spatial expansion and land use change.
\end{abstract}

Keywords Urbanization · Socio-political · Municipality · Urban expansion · Riparian zone

\section{Introduction}

Urban sprawling refers to the growth of urban areas resulting from uncontrolled, uncoordinated and unplanned growth [29]. In most cities around the world, the urban growth phenomena have become unsustainable in many respects [2]. Moreover, urbanization itself is a common concern throughout the world where people leave rural areas and accumulate in major cities [3].

Urbanization either spreads radially around a wellestablished city or linearly along the highways, which is often referred to as sprawl dispersed development [37]. Normally, a settlement which is controlled by the natural factors including flat area, rivers, and mountains is described as the clustered settlement pattern [30]. Soran district urbanization pattern can be described as clustered settlement since it is surrounded by rivers and mountains.

Humans have influenced the Earth environment by changing the dynamics of land use/land cover [15]. In the last five decades, human activities around the world negatively affected most of land use land cover (LULC) categories [16]. The land has become scarce because of the enormous agricultural and population pressure [33]. The farmland displacement, urban sprawl, and deforestation, which leads to habitat destruction, loss of arable land, and to the decline of natural greenery areas are characteristics of rapid land cover change [39].

LULC rapid change is attributed to several direct and potential sprawling factors [17]. Direct factors would involve the infrastructure construction, settlement

\footnotetext{
$\triangle$ Rahel Hamad, rahel.hamad@soran.edu.iq | ${ }^{1}$ Department of Petroleum Geosciences, Faculty of Science, Delzyan Campus, Soran University, Soran, Erbil 44008, Iraq. ${ }^{2}$ GIS and Remote Sensing Department, Scientific Research Centre (SRC), Delzyan Campus, Soran University, Soran, Erbil 44008, Iraq.
} 
expansion, and industry development factors, whereas potential factors include technology, economy, population, policies, wars, and natural factors [9].

On the other hand, another relevant factor that supports growth and development in cities is the transportation infrastructure of primary and secondary road networks [5] that show the spatial structure of population distribution [43]. Consequently, urban expansion and transportation are essentially interrelated [23]. These landscape dynamics can be well understood using multitemporal satellite imagery for digital change detection techniques [33].

The significance of this work highlights the challenges embedded in the analysis of an urban sprawl in the very rapid development of Soran district in Kurdistan following the 1990-2003 major postwar socio-political upheaval in Iraq, and secondly, it demonstrates that sprawl is a real and measurable phenomenon. Thus, analyzing the sprawl over a period of time through RS and GIS techniques will help in understanding the nature and growth of this phenomenon, which suggests the future directions and patterns of sprawling growth.

Satellite images are significant source for land use/land cover information as they offer rapid, periodic and accurate data acquisition from RS [40] system. Landsat data are widely used in the study of the LULC change. Information on LULC change and urban growth study is essential for urban planners and local governments futuristic plans for sustainable development in any area [38].

One of the most relevant factors that relates to RS is classification. Certain types of algorithms are used to provide suitable classification accuracy [28]. Maximum likelihood classification (MLC), the most commonly supervised method, was used. In this context, the training areas are used in supervised technique [13]. The mapping of LULC can be delineated from fine and coarse resolutions [31].

Landsat TM, ETM+ and LOL [14], Satellite Pour I'Observation de la Terre (SPOT) [11], Advanced Spaceborne Thermal Emission and Reflection Radiometer (ASTER) [1], Ikonos (Pereiraa and Caetanoa, [32]), Pleiades [12], Worldview [22], and aerial photographs [20] have been employed in the mapping analysis of land use classes and in the monitoring of their changes.

Soran district has expanded rapidly in the 1990s into a large city. It has gained real importance from 1991 onwards due to its strategic location on a major international commercial route, which resulted in considerable spread with the establishment of new residential and commercial areas. Furthermore, and following the imposition of food and petrol products embargo on Kurdistan region by the former Iraqi regime from October 1991 onwards, almost two-thirds of the United Nations (UN) budget for humanitarian operations in Iraq went to the three northern governorates: Erbil, Sulaymaniyah and Duhok. Thus, a'winterization plan' was launched by UN, which involved food and kerosene distribution in these three Northern governorates. It is worth to mention that, the Non-Governmental Organizations (NGOs) such as UNICEF (United Nations Children's Fund), the World Food Program (WFP), and CARE International had a significant role in goods distribution. As a result, these improvements encouraged the refugees to return back [25]. Therefore, Soran district was one of the cities that has enjoyed a period of economic development, enhanced political stability, and a growing local recognition especially after April 9, 2003 or Post-Saddam period [36].

\section{Materials and methods}

\subsection{Study area}

Soran district is located in the northeast of Erbil governorate about $100 \mathrm{~km}$ from the Erbil city center. It is surrounded by several major mountain ranges, including the mountains of Korek, Handren, Zozk, Hassan Bag, and Bradost. Thus, winter snowfall is common on these mountains. The study area was carried out on the Soran municipality with a geographical coordinates $36^{\circ} 42^{\prime} 04^{\prime \prime} \mathrm{N}$ to $36^{\circ}$ $37^{\prime} 30^{\prime \prime} \mathrm{N}$ latitude and $44^{\circ} 30^{\prime} 01^{\prime \prime}$ to $44^{\circ} 34^{\prime} 30^{\prime \prime}$ E longitude at an average altitude of $700 \mathrm{~m}$ above sea level, covering an administrative area spread over 43 square kilometers (Fig. 1). Soran district is a residential, industrial and agricultural area.

Soran district has hot, dry summers, and cool to cold, damp, humid winters (Soran Iraqi kurdistan, [35]). The mean monthly temperature recorded in Soran station is

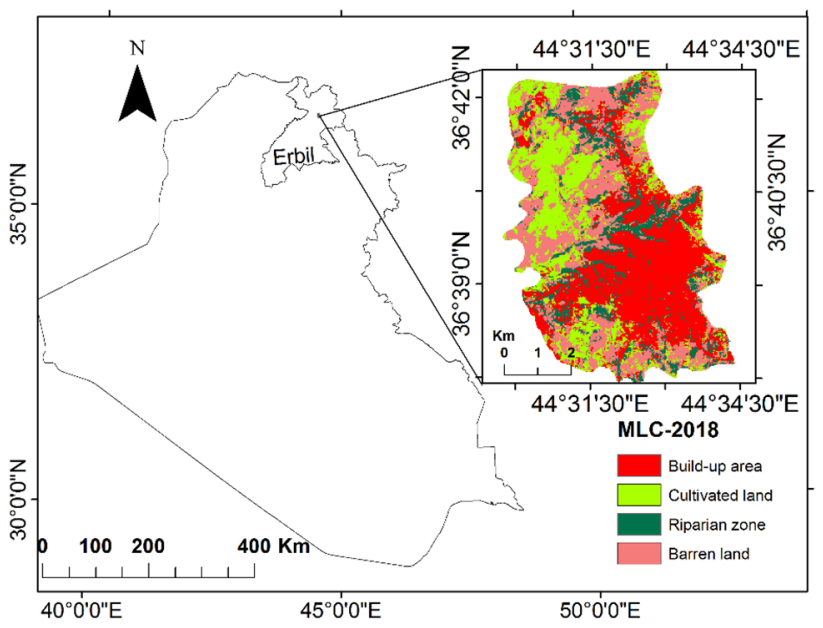

Fig. 1 Location map of Soran district in the Kurdistan Region of Iraq 
$10^{\circ} \mathrm{C}$ in January and $40^{\circ} \mathrm{C}$ in July. Precipitation is highly seasonal and peaks during November and April.

Soran city stands as a strong example of explosive urban growth following a major political upheaval and demographic change. Kurdish refugees started to return to Soran district from Iran as early as the 1990s, having fled to Iran between 1974 and 1989 during the second Iraqi-Kurdish War and the Al-Anfal Campaign. As a result of this influx, the population grew in 1991 from 27,000 (Soran Iraqi kurdistan, [35]) to about 196,895 in 2018 according to Kurdistan Regional Statistics Office [24]. Consequently, Soran district passes through a tremendous urban pressure as a result of unusual rapid population growth after 2003 .

Researchers have widely addressed the impacts of population growth on urban sprawl. El Garouani et al. [10] highlighted the acceleration rate of population growth that has generated a large urban sprawl of Fez city in Morocco. Hegazy and Kaloop [18] argued how Mansoura and Talkha cities in Daqahlia governorate in Egypt are expanding rapidly with varying growth rates and patterns, whereas Belal and Moghanm [7] showed the case of urban expansion that causes loss of productive agricultural lands in Tanta and Quttour districts in Egypt. Finally, measuring the LULC change is necessary for future urban planning at local and global level reported Singh and Singh [34].

This study analyzes the urban sprawl of Soran district in the past two decades and shows how various features have affected the spatial pattern of this urban sprawl.

Table 1 Information of satellite data used for this study

\begin{tabular}{lllll}
\hline Satellite data & $\begin{array}{l}\text { Acquisition } \\
\text { date }\end{array}$ & Path/row & $\begin{array}{l}\text { Spatial } \\
\text { res. } \\
(\mathrm{m})\end{array}$ & Bands \\
\hline $\begin{array}{l}\text { Landsat 7 } \\
\text { ETM+ }\end{array}$ & 25 August 1998 & $169 / 035$ & 30 & $1,2,3,4,5,7$ \\
$\begin{array}{c}\text { Landsat 5 TM } \\
\text { Landsat 8 OLI }\end{array}$ & $\begin{array}{l}\text { 19 July 2008 } \\
\text { 28 September } \\
\text { 2018 }\end{array}$ & $169 / 035$ & 30 & $1,2,3,4,5,7$ \\
& $169 / 035$ & 30 & $2,3,4,5,6,7$ \\
\hline
\end{tabular}

\subsection{Data used}

Digital image processing of ETM+ in the 1998 (spatial resolution $30 \mathrm{~m})$, TM acquired in the $2008(30 \mathrm{~m})$, and LOL in the $2018(30 \mathrm{~m})$ were treated by ENVI 5.3 and ARCGIS 10.3 software. The images were used to explore the land use/land cover change and to estimate physical extent of urban area of Soran district for three-time series during the same season. Table 1 shows the information related to the satellite images used in this study.

Three scenes during the dry season of Landsat imagery $30 \mathrm{~m}$ resolution were downloaded from Earth Explorer (USGS) [42]. The dry season provides a better view of the surface although distinguishing wetlands from other types of vegetation. The obtained images were clipped with Soran municipality boundaries. The land cover types found in the area included build-up areas, barren land, cultivated land and riparian zone.

The scenes were selected to be geometrically corrected and calibrated. The data of ground truth were adapted for each single classifier produced by its spectral signatures for producing series of classification maps.

\subsection{Classification system}

A modified version of the Anderson LULC classification system [4] was used in this study. Classification scheme and detailed descriptions are given in Table 2. A MLC, which is a supervised classification system and is the most popularly used algorithm in image classification [17, 19], was applied for LULC mapping from the three images. Six bands except thermal bands for Landsat 5, 7 and 8 were used as input for maximum likelihood classification system. A total of two hundred and forty sampling points, sixty sampling points for each class in the city of Soran district, were collected to compare the uses of existing situation of satellite images. Training sites were carefully selected using high resolution from images; worldview 2 image $(50 \mathrm{~cm})$ to compare image Landsat 5 TM 2008 and Pleiades $(50 \mathrm{~cm})$ to compare it with $2018 \mathrm{OLI}$ satellite image, whereas for Landsat image 7 ETM+1998 an expert knowledge of the study was gained from the Municipality Department of Soran district.
Table 2 Land use/land cover classes used in this article and their descriptions

\begin{tabular}{ll}
\hline Class name & Description \\
\hline Urban/built-up area & Residential, industrial, transportation and communications \\
Barren land & $\begin{array}{c}\text { Area of thin soil, sand and mountain rocks almost having } \\
\text { no vegetation }\end{array}$ \\
Riparian zone & The interface between land and a stream \\
Cultivated land & Crop fields and vegetable lands
\end{tabular}


Thus, these images were used as base maps to maximize the accuracy of classification in the images.

Concerning the accuracy assessment, a confusion matrix, which is a table that shows correspondence between the result of a classification and a reference image, was used as the quantitative method of characterizing image classification accuracy. Pixel values were extracted from reference points, created an error matrix, calculated the overall percent accuracy, and the user's and producer's accuracies [26].

Soran district was divided into four zones from the central pixel based on spatial directions. The spatial directions approach is carried out according to known geographical trends, either four or eight. Four directions (instead of eight) were selected in this approach to quantitatively and spatially obtain additional details about the studied case for a realistic evaluation that would support planners and decision makers in Soran district create sustainable plans for the future [2].

\section{Result visualization}

\subsection{Classification accuracy assessment}

Tables 3, 4, 5 show the accuracy assessment with overall accuracy, producer's accuracy, user's accuracy, and Kappa coefficient for the classified maps for 1998, 2008, and 2018 [26]. Moreover, the overall classification accuracies for 1998,2008 and 2018 are $74 \%, 86 \%$ and $88 \%$, respectively. The Kappa coefficient for 1998, 2008 and 2018 images is $0.65,0.81$ and 0.84 , respectively.

\subsection{Landscape structure and dynamics}

The classified images provide the information about the land use pattern of the study area. The red color represents the urban built-up area, light green color shows the cultivated land, dark green color shows the riparian zone, and orange color shows the barren land. The LULC maps are shown in (Fig. 2) for three points in time. The directions in
Table 3 Error matrix of the land use/land cover map for year 1998
Table 4 Error matrix of land use/land cover map for year 2008

\begin{tabular}{|c|c|c|c|c|c|c|}
\hline \multicolumn{7}{|l|}{ Landsat 7 ETM+(1998) } \\
\hline Class & 1 & 2 & 3 & 4 & Total & $\begin{array}{l}\text { User's } \\
\text { accuracy } \\
(\%)\end{array}$ \\
\hline 1-Build-up area & 43 & 5 & 7 & 6 & 61 & 70 \\
\hline 2-Cultivated land & 7 & 42 & 6 & 4 & 59 & 71 \\
\hline 3-Riparian zone & 3 & 6 & 47 & 4 & 60 & 78 \\
\hline 4-Barren land & 5 & 5 & 4 & 46 & 60 & 74 \\
\hline Total & 58 & 58 & 64 & 60 & 240 & \\
\hline Producer's accuracy & 74 & 72 & 73 & 77 & & \\
\hline Overall accuracy & $\% 74$ & & & & & \\
\hline Kappa & 0.65 & & & & & \\
\hline
\end{tabular}

\begin{tabular}{|c|c|c|c|c|c|c|}
\hline \multicolumn{7}{|l|}{ Landsat 5 TM (2008) } \\
\hline Class & 1 & 2 & 3 & 4 & Total & $\begin{array}{l}\text { User's } \\
\text { accuracy } \\
(\%)\end{array}$ \\
\hline 1-Build-up area & 52 & 3 & 2 & 3 & 60 & 86 \\
\hline 2-Cultivated land & 3 & 51 & 4 & 2 & 60 & 85 \\
\hline 3-Riparian zone & 1 & 2 & 53 & 3 & 59 & 89 \\
\hline 4-Barren land & 2 & 4 & 3 & 52 & 61 & 85 \\
\hline Total & 58 & 60 & 62 & 60 & 240 & \\
\hline Producer's accuracy & 89 & 85 & 85 & 86 & & \\
\hline Overall accuracy & $\% 86$ & & & & & \\
\hline Kappa & 0.81 & & & & & \\
\hline
\end{tabular}


Table 5 Error matrix of land use/land cover map for year 2018

\begin{tabular}{|c|c|c|c|c|c|c|}
\hline \multicolumn{7}{|l|}{ Landsat OLI (2018) } \\
\hline Class & 1 & 2 & 3 & 4 & Total & $\begin{array}{l}\text { User's } \\
\text { accuracy } \\
(\%)\end{array}$ \\
\hline 1-Build-up area & 53 & 3 & 2 & 3 & 61 & 87 \\
\hline 2-Cultivated land & 4 & 52 & 2 & 1 & 59 & 88 \\
\hline 3-Riparian zone & 1 & 2 & 54 & 3 & 60 & 90 \\
\hline 4-Barren land & 2 & 4 & 1 & 53 & 60 & 88 \\
\hline Total & 60 & 61 & 59 & 60 & 240 & \\
\hline Producer's accuracy & 88 & 85 & 91 & 88 & & \\
\hline Overall accuracy & $\% 88$ & & & & & \\
\hline Карра & 0.84 & & & & & \\
\hline
\end{tabular}
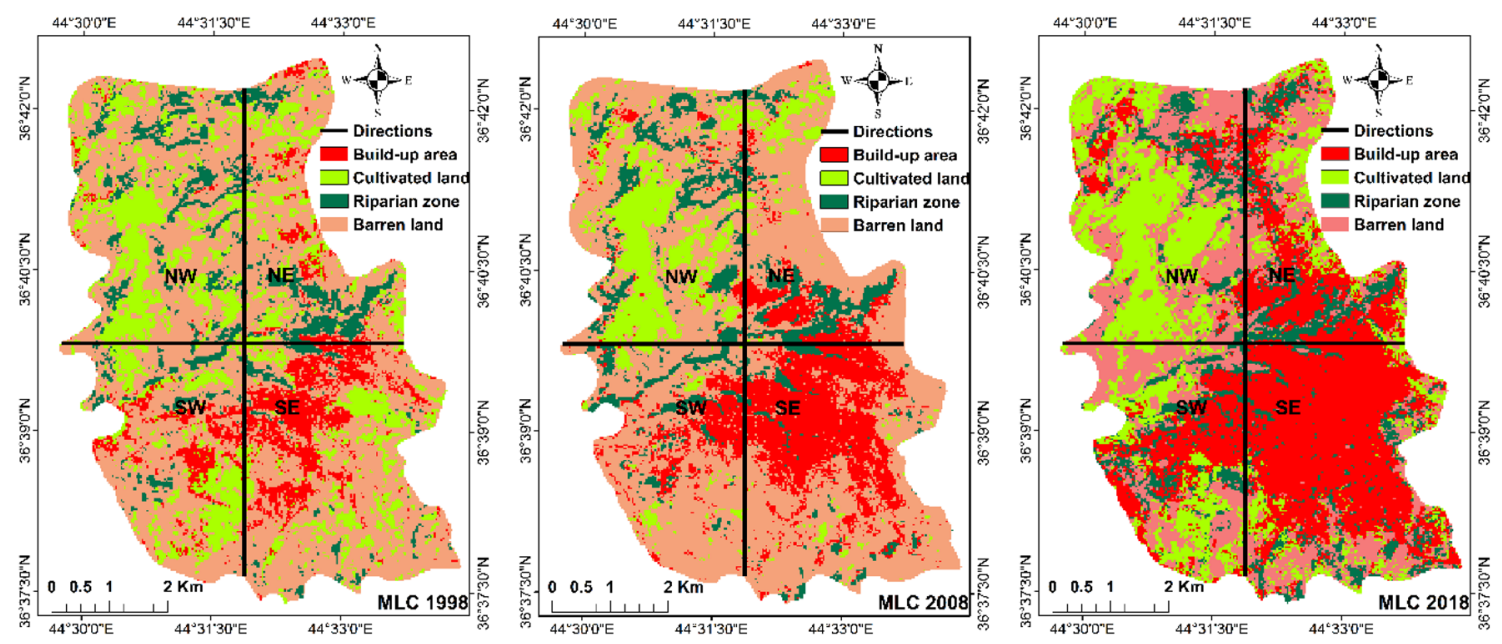

Fig. 2 LULC distribution and zone maps of Soran district from classification using maximum likelihood classification for years 1998, 2008, and 2018

this study were northeast (NE), southwest (SW), northwest (NW), and southeast (SE).

The increased expansion of road infrastructure has its effect on urban expansion (Fig. 3). Moreover, lands in Soran district are being consumed at a faster rate in the centre growth and toward the SE in correlation with road infrastructure expansion increased with increasing population in 2018. More line roads are being constructed in 2018 outward from urban centers, which is also a prominent characteristic of sprawl.

\subsection{Post classification comparison}

The spatial distributions of the classes were extracted from each of the LULC distribution for the three images and are presented in Table 6.

The urban built-up area class increased significantly from $10.49 \%$ in 1998 to $18.91 \%$ in 2008 , then after to $34.73 \%$ in 2018 . Cultivated land decreased from $21.38 \%$ in 1998 to $12.07 \%$ in 2008 and increased rapidly to $23.97 \%$ in 2018 . A steady increase in riparian zone can be observed from $9.16 \%$ in 1998 to $10.63 \%$ in 2008 , and then to $12.84 \%$ in 2018 . On the other hand, barren land that existed in 1998 remained as it was in 2008, whereas the rate decreased sharply to $28.46 \%$ in 2018 . Thus, the results show an expansion of urban/built-up areas in 2018, on the expense of barren areas decrease.

\section{Discussion}

\subsection{Urban Sprawl expansion}

The results brought out significant urban expansion of the city for the period 1998-2018. Hence, the built-up land has expanded more than threefold during the last 20 years from 4.51 to $14.93 \mathrm{~km}^{2}$ showing a positive trend over time. However, the barren land is under stress due to population 

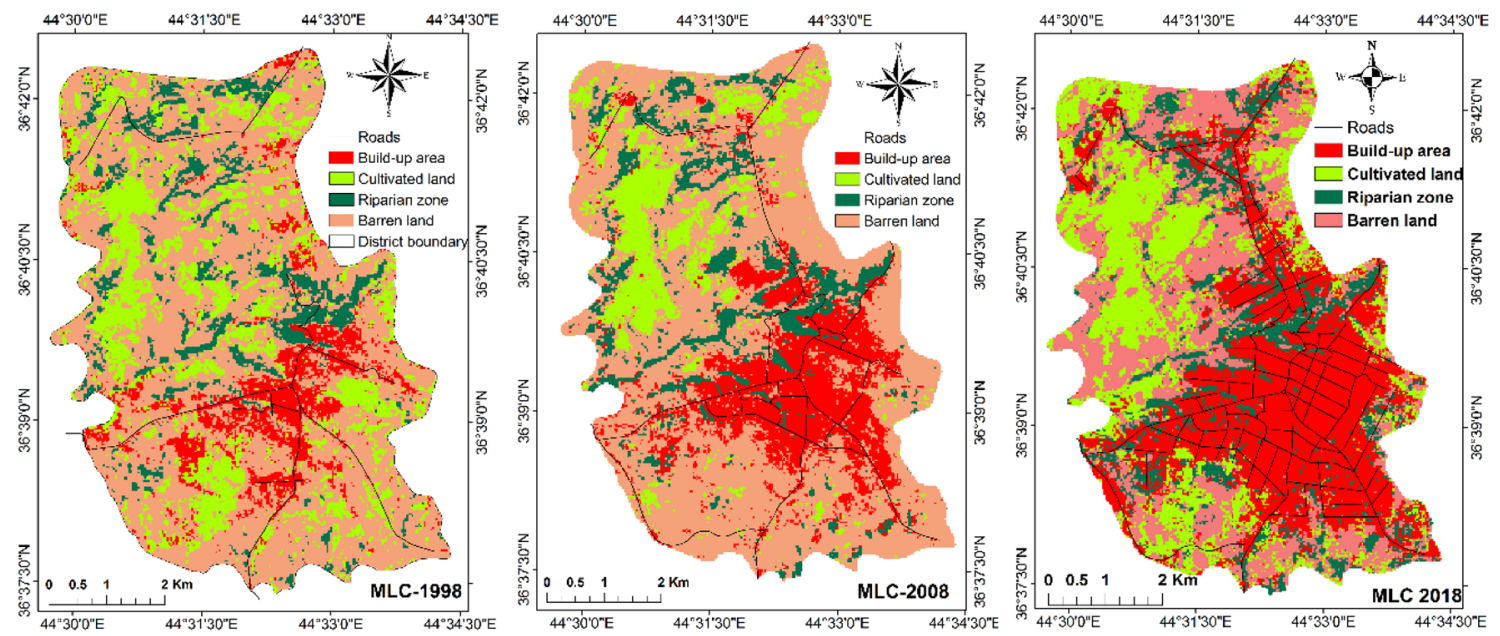

Fig. 3 Urban growth map based on land use changes and road network expansion of Soran district from classification using maximum likelihood classification for years 1998, 2008, and 2018

Table 6 Results of land use/ land cover classification statistics for 1998, 2008 and 2018 in square kilometers and percent

\begin{tabular}{|c|c|c|c|c|c|c|}
\hline \multirow[t]{2}{*}{ Class name } & \multicolumn{2}{|l|}{1998} & \multicolumn{2}{|l|}{2008} & \multicolumn{2}{|l|}{2018} \\
\hline & $\mathrm{km}^{2}$ & $\%$ & $\mathrm{~km}^{2}$ & $\%$ & $\mathrm{~km}^{2}$ & $\%$ \\
\hline Build-up area & 4.51 & 10.49 & 8.13 & 18.91 & 14.93 & 34.73 \\
\hline Cultivated land & 9.19 & 21.38 & 5.18 & 12.07 & 10.31 & 23.97 \\
\hline Riparian zone & 3.91 & 9.16 & 4.57 & 10.63 & 5.63 & 12.84 \\
\hline Barren land & 25.39 & 58.97 & 25.12 & 58.39 & 12.13 & 28.46 \\
\hline Total & 43 & $100 \%$ & 43 & $100 \%$ & 43 & $100 \%$ \\
\hline
\end{tabular}

pressure and the associated demand for urban expansion (Table 6 and Fig. 4).

In order to identify, describe, and quantify differences between images of the same scene at different times, a GIS has been used to integrate urban/built-up areas class for the three images and generate a thematic map to examine dynamics of urban expansion. This analysis allowed to identify several changes occurring in different classes of the land use. The classified land use maps of built-up area and their spatial distributions for years 1998, 2008 and 2018 are shown in Fig. 4.

During the three periods, the encroachment of urban/ built-up areas occurred to the direction of SE from the center of Soran district since 1998 as shown in Table 7, where the classified results indicate that the city is expanding and fanning out in the SE, NE and SW parts of the city. These areas are less hilly with no agricultural activities.

During the period 1998-2018, the NE zone grew by $2.33 \mathrm{~km}^{2}$, the SE zone grew by $5.64 \mathrm{~km}^{2}$ which has the maximum growth zone, and the SW zone grew by $1.49 \mathrm{~km}^{2}$, while the NW zone grew by $0.86 \mathrm{~km}^{2}$ (Table 8 ). Thus, the SE zone witnessed the largest growth, contrasted by the lowest NW growth marking the SE as general active growth direction. This growth orientation could partly be caused by the international Hamilton road, which is a spectacular winding mountain road from Erbil to Iran and one of the most strategically important roads.

Numerically, since 1998, urban built-up areas of Soran district have been expanding at a faster rate especially in the last decade (2008-2018). Built-up area of the town was about $4.51 \mathrm{~km}^{2}$ in $1998,8.13 \mathrm{~km}^{2}$ in 2008 , and $14.13 \mathrm{~km}^{2}$ in 2018 (Table 6). On average, the rate of expansion of the town was $0.36 \mathrm{~km}^{2}$ per annum in the first decade (1998-2008) and about $0.68 \mathrm{~km}^{2}$ in the second period (2008-2018). Thus, change detection resulted in evolution of urban areas and its implication with barren land, which revealed that the development in Soran district has developed as sprawl area.

As can be observed from Table 6 in 1998 and 2008, the majority of the area (about $25.39 \mathrm{~km}^{2}$ and $25.12 \mathrm{~km}^{2}$, out of $43 \mathrm{~km}^{2}$ of the study area) in Soran district was barren land. Whereas in 2018 the build-up area dominated and covered $14.93 \mathrm{~km}^{2}$ out of $43 \mathrm{~km}^{2}$, then barren land took second class and covered $12.13 \mathrm{~km}^{2}$. The urban expansion of Soran district was largely caused by the increasing built-up area of the town from $10.49 \%$ in 1998 to $34.73 \%$ in 2018 . This in turn is due to the natural increase 


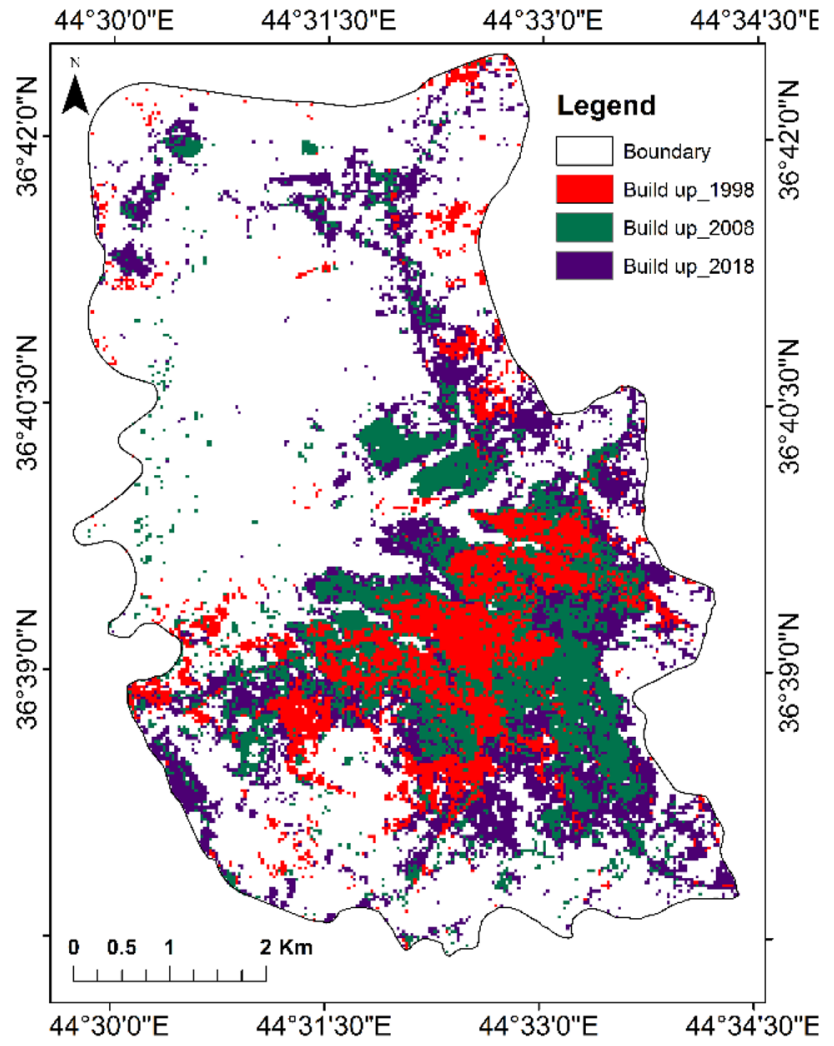

Fig. 4 The spatial changes of the urban expansion of Soran district in 1998,2008 , and 2018 . Showing a steady increase in urban/builtup areas from 1998 to 2018

Table 7 Urban areas in $\mathrm{km}^{2}$ in all zones from 1998 to 2018

Years $\mathrm{NE}\left(\mathrm{km}^{2}\right) \quad \mathrm{SE}\left(\mathrm{km}^{2}\right) \quad \mathrm{SW}\left(\mathrm{km}^{2}\right) \quad \mathrm{NW}\left(\mathrm{km}^{2}\right) \quad$ Whole city $\left(\mathrm{km}^{2}\right)$

\begin{tabular}{rrrrrr}
\hline 1998 & 0.62 & 2.64 & 1.05 & 0.13 & 4.44 \\
2008 & 1.12 & 5.06 & 1.47 & 0.37 & 8.02 \\
2018 & 2.95 & 8.28 & 2.54 & 0.99 & 14.76 \\
\hline
\end{tabular}

in the population and rural to urban migration. Furthermore, most of these returnees were unable to return to their original villages which had been destroyed by the Iraqi regime's army or unwilling to return to locations, and instead settled in Soran district [14]. Moreover, push and pull factors explain the processes that attract migrants to the new location and clarify why people migrate from countryside to urban areas [16].

On the other hand, barren land has declined from 25.39 $\mathrm{km}^{2}(58.97 \%)$ in 1998 to $12.13 \mathrm{~km}^{2}(28.46 \%)$ in 2018 . The decline of barren land was largest, and it was as high as $30.51 \%$. Areas covered by riparian zone have increased by $0.66 \mathrm{~km}^{2}$ in the first period (1998-2008) and by $2.21 \mathrm{~km}^{2}$ in the second period (2008-2018). A significant change of cultivated land can be observed as it declined sharply in the first period from $21.38 \%$ in 1998 to $12.07 \%$ in 2008 , but the change in second period was reversed, as it increased from $12.07 \%$ in 2008 to $23.97 \%$ in 2018 . The expansions of build-up area and cultivation increase are directly related to the socioeconomic boom after the Fall of Baghdad in 2003. The people are increasingly trying to allocate comfort farms and summer houses, as a way of a more relaxed and prosperous way of life in the community.

The residential land use has the largest share of the built-up area in all times. Moreover, from 1998 to 2008, the built-up area increased by $8.02 \mathrm{~km}^{2}$. The next period of physical expansion of the city was between 2008 and 2018 , when the built-up area expanded by $14.76 \mathrm{~km}^{2}$ (Fig. 5).

In order to evaluate whether the build-up areas are growing equally, four zones of the study area were selected namely NE, SE, SW, and NW. As shown in Fig. 6, the rate of expansion for these zones for the 1998-2008 period is $0.5,2.42,0.42$ and $0.24 \mathrm{~km}^{2} /$ year and $1.83,3.22$, 1.07 and $0.62 \mathrm{~km}^{2} /$ year for the second period 2008-2018, respectively, which indicate that the SE zone witnessed the largest growth and NW witnessed the smallest growth, meaning that the study area grew mainly in a south easterly direction.

The impact of urban sprawl is seen mainly on barren land that decreased from 25.39 to $12.13 \mathrm{~km}^{2}$; thus, new urban development occurs mainly on barren land. The residential colonies have grown in the SE and $\mathrm{NE}$, then SW parts, while the rest of the city still depicts dispersed builtup land patterns. The study had an overall classification accuracy of $81.7 \%$ and kappa coefficient of 0.722 .

Researchers have focused on successful remotely sensed classification as an essential source for many application processes [28]. The classification technique used to derive the LULC maps for 1998, 2008 and 2018
Table 8 Observed growth in urban area $\left(\mathrm{km}^{2}\right)$

\begin{tabular}{lllllc}
\hline Years & NE $\left(\mathrm{km}^{2}\right)$ & SE $\left(\mathrm{km}^{2}\right)$ & SW $\left(\mathrm{km}^{2}\right)$ & NW $\left(\mathrm{km}^{2}\right)$ & $\begin{array}{r}\text { Total } \\
\text { change } \\
\left(\mathrm{km}^{2}\right)\end{array}$ \\
\hline Change 1998-2008 & 0.50 & 2.42 & 0.42 & 0.24 & 3.58 \\
Change 2008-2018 & 1.83 & 3.22 & 1.07 & 0.62 & 6.74 \\
Total & 2.33 & 5.64 & 1.49 & 0.86 & 10.32 \\
\hline
\end{tabular}




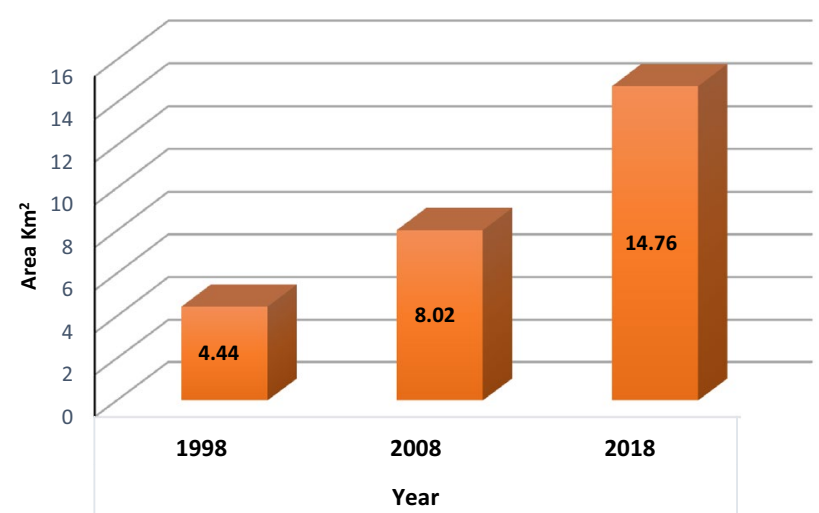

Fig. 5 Built-up area in 1998, 2008 and 2018 in $\mathrm{km}^{2}$

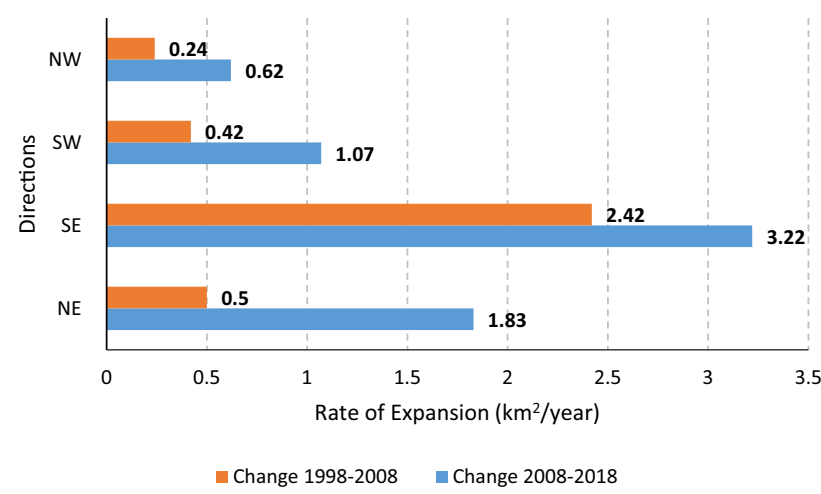

Fig. 6 Rate of expansion of urban areas in the periods 1998-2008 and $2008-2018$

was MLC. The kappa coefficient for year 1998 was rated as substantial agreement 0.65 , while for images 2008 and 2018 had the Kappa coefficients of 0.81 and 0.84 , respectively, reflecting almost perfect agreement ([6]; [8]). However, the supervised classification produced good results with overall accuracies of $74 \%, 86 \%$, and $88 \%$ for the years 1998,2008 , and 2018 , respectively. One possible reason for variance between accuracies 1998 with 2008 and 2018 is that the high-resolution images worldview $2(50 \mathrm{~cm})$ and Pleiades $(50 \mathrm{~cm})$, which were treated as the reference data for the 2008 and 2018 Landsat images, respectively, are more precise than Landsat image 1998 that the expert knowledge from the Municipality Department of Soran district was interpreted.

Additionally, the land cover updating using RS classification techniques is an essential task especially in a rapidly urbanizing region, where fast development makes it necessary to monitor land cover change in a timely manner [27]. The updating is based on the application of digital interpretation techniques of high-resolution satellite data.
The data in a GIS have to be updated in order to maintain a valid representation of the 'real world' [21].

To conclude, the period 1998-2018 witnessed a rapid population growth, spatial expansion, land use change, advanced road construction and densification of central city, which usually mark the historical origins of growth and road infrastructure expansion [41].

\section{Conclusions}

Urban growth change and trend in Soran district were computed and assessed by using three different points 1998, 2008, and 2018 using GIS and remote sensing in order to evaluate the urban growth and sprawl patterns and to produce the land use and land cover map for the studied area. Rapid urbanization has led to significant changes. Urban expansion in Soran district during last 20 years effected the land resources, as well as a potential decrease in water quantity and quality in the town. It has pointed out that Soran district has experienced substantial changes in land cover and land use since the end of 1990s. These changes are induced by upgrading of many urban roads or construction of new road linked structures. Furthermore, the sprawl in Soran district particularly in the north and NE part occurs in disorderly and unplanned patterns, influenced by the proximity of villages and land rents. Further research is encouraged to use proper measures in accordance with scientific planning for the urban expansion of the city in the future.

Acknowledgements Many thanks to Dr. K. Kolo of the Scientific Research Centre (SRC) at Soran University for valuable comments on manuscript and to the (SRC) for providing the reference images.

\section{Compliance with ethical standards}

Conflict of interests Author has declared that no competing interests exist.

\section{References}

1. Abrams M, Tsu H, Hulley $G$ et al (2015) The advanced spaceborne thermal emission and reflection radiometer (ASTER) after fifteen years: review of global products. Int J Appl Earth Obs Geoinf 38:292-301

2. Aburas MM, Ho YM, Ramli MF et al (2018) Monitoring and assessment of urban growth patterns using spatio-temporal built-up area analysis. Environ Monit Assess 190:156

3. Ali JM, Marsh SH, Smith MJ (2017) A comparison between London and Baghdad surface urban heat islands and possible engineering mitigation solutions. Sustain Cities Soc 29:159-168 
4. Anderson JR (1976) A land use and land cover classification system for use with remote sensor data. US Government Printing Office

5. Banerjee A, Duflo E and Qian N (2012) On the road: access to transportation infrastructure and economic growth in China. National Bureau of Economic Research

6. Bayarsaikhan U, Boldgiv B, Kim K-R et al (2009) Change detection and classification of land cover at Hustai National Park in Mongolia. Int J Appl Earth Obs Geoinf 11:273-280

7. Belal A, Moghanm F (2011) Detecting urban growth using remote sensing and GIS techniques in Al Gharbiya governorate, Egypt. Egypt J Remote Sens Space Sci 14:73-79

8. Bwangoy J-RB, Hansen MC, Roy DP et al (2010) Wetland mapping in the Congo Basin using optical and radar remotely sensed data and derived topographical indices. Remote Sens Environ 114:73-86

9. Chen L, Ren C, Zhang B et al (2018) Quantifying urban land sprawl and its driving forces in northeast China from 1990 to 2015. Sustainability 10:188

10. El Garouani A, Mulla DJ, El Garouani S et al (2017) Analysis of urban growth and sprawl from remote sensing data: case of Fez, Morocco. Int J Sustain Built Environ 6:160-169

11. Flood N (2017) Comparing Sentinel-2A and Landsat 7 and 8 using surface reflectance over Australia. Remote Sens 9:659

12. Gleyzes MA, Perret L, Kubik P (2012) Pleiades system architecture and main performances. Int Arch Photogramm Remote Sens Spat Inf Sci 39:537-542

13. Gupta GR, Kamalapur SM (2014) Study of classification of remote sensing images using particle swarm optimization based approach. IJAIEM 3(10):165-169

14. Hamad R, Balzter H, Kolo K (2017) Multi-criteria assessment of land cover dynamic changes in halgurd sakran national park (HSNP), kurdistan region of Iraq, using remote sensing and GIS. Land 6:18

15. Hamad R, Balzter H, Kolo K (2018) Predicting land use/land cover changes using a CA-Markov model under two different scenarios. Sustainability 10:3421

16. Hamad R, Kolo K, Balzter H (2018) Land cover changes induced by demining operations in Halgurd-Sakran National Park in the Kurdistan Region of Iraq. Sustainability 10:2422

17. Hamad R, Kolo K, Balzter H (2018) Post-war land cover changes and fragmentation in Halgurd Sakran National Park (HSNP), Kurdistan region of Iraq. Land 7:38

18. Hegazy IR, Kaloop MR (2015) Monitoring urban growth and land use change detection with GIS and remote sensing techniques in Daqahlia governorate Egypt. Int J Sustain Built Environ 4:117-124

19. Huang C, Davis L, Townshend J (2002) An assessment of support vector machines for land cover classification. Int J Remote Sens 23:725-749

20. Jacobsen K (2011) Characteristics of very high resolution optical satellites for topographic mapping. In: International archives of the photogrammetry, remote sensing and spatial information sciences: ISPRS Hannover workshop 2011-high-resolution earth imaging for geospatial information 38-4 (2011), Nr. W19. Göttingen: Copernicus GmbH, pp 137-142

21. Janssen $L$ (1994) Methodology for updating terrain object data from remote sensing data: the application of Landsat TM data with respect to agricultural fields. Janssen. ISBN:90-5485-181-3

22. Jawak SD, Luis AJ (2011) Applications of WorldView-2 satellite data for extraction of polar spatial information and DEM of Larsemann Hills, East Antarctica. In: International conference on fuzzy systems and neural computing (FSNC 2011), pp 978-971

23. Kashem SB, Irawan A, Wilson B (2014) Evaluating the dynamic impacts of urban form on transportation and environmental outcomes in US cities. Int J Environ Sci Technol 11:2233-2244
24. KRSO (2018) Ministry of Planning 2018. Kurdistan Regional Statistics Office-KRSO. http://www.mop.gov.krd. Accessed 25 Mar 2019

25. Leezenberg M (2000) Humanitarian Aid in Iraqi Kurdistan. CEMOTI, Cahiers d'Études sur la Méditerranée Orientale et le monde Turco-Iranien 29:31-49

26. Lillesand T, Kiefer RW, Chipman J (2015) Remote sensing and image interpretation. Wiley, Hoboken

27. Lin C, Du P, Samat A et al (2019) Automatic updating of land cover maps in rapidly urbanizing regions by relational knowledge transferring from GlobeLand30. Remote Sens 11:1397

28. Lu D, Hetrick S, Moran E (2011) Impervious surface mapping with Quickbird imagery. Int J Remote Sens 32:2519-2533

29. Noor NM, Rosni NA (2013) Determination of spatial factors in measuring urban sprawl in Kuantan using remote sensing and GIS. Proc Soc Behav Sci 85:502-512

30. Ourng $C$ and Rodrigues DS. (2012) Urban growth pattern identification: A case study in Siem Reap, Cambodia. In PLURIS 2012$5^{\circ}$ Congresso Luso-Brasileiro para o Planejamento Urbano, Regional, Integrado e Sustentável. Universidade de Brasília. Faculdade de Arquitetura e Urbanismo, pp 1-11

31. Paliwal A, Mathur VB (2014) Spatial pattern analysis for quantification of landscape structure of Tadoba-Andhari Tiger Reserve, Central India. J For Res 25:185-192

32. Pereiraa MdC, Caetanoa M (2005) Use of very high spatial resolution satellite imagery for thematic applications: a review. In: Proceedings of the 31 international symposium on remote sensing of environment, pp 20-24

33. Rawat J, Kumar M (2015) Monitoring land use/cover change using remote sensing and GIS techniques: a case study of Hawalbagh block, district Almora, Uttarakhand, India. Egypt J Remote Sens Space Sci 18:77-84

34. Singh B, Singh J (2014) Land use/land cover change of Delhi: a study using remote sensing and GIS techniques. ISSN $2321-2527$

35. Soran Iraqi kurdistan. (2019) Soran, Iraq. Available online: Iraqi kurdistan. https://en.wikipedia.org/wiki/Soran,_Iraq. Accessed 3 Mar 2019

36. Stansfield GR (2003) Iraqi Kurdistan: political development and emergent democracy. Routledge, Abingdon

37. Sudhira H, Ramachandra T, Jagadish K (2003) Urban sprawl pattern recognition and modeling using GIS. In: Proceeding Map India-2003, New Delhi

38. Sundarakumar K, Harika M, Begum SA et al (2012) Land use and land cover change detection and urban sprawl analysis of Vijayawada city using multitemporal landsat data. Int J Eng Sci Technol 4:170-178

39. Swerts E, Pumain D, Denis E (2014) The future of India's urbanization. Futures 56:43-52

40. Topaloğlu RH, Sertel E, Musaoğlu N (2016) Assessment of classification accuracies of Sentinel-2 and Landsat-8 data for land cover/use mapping. Int Arch Photogramm Remote Sens Spat Inform Sci 41(B8):1055-1059

41. Tsai Y-H (2005) Quantifying urban form: compactness versus' sprawl'. Urban Stud 42:141-161

42. USGS. United State Geological Survey science (USGS) for a changing world. http://earthexplorer.usgs.gov. Accessed 13 Jan 2019

43. Zhao F, Sun H, Wu J et al (2016) Analysis of road network pattern considering population distribution and central business district. PLoS ONE 11:e0151676

Publisher's Note Springer Nature remains neutral with regard to jurisdictional claims in published maps and institutional affiliations. 